\title{
«Oberexia»: The desire to be fat(ter) in adults with excess weight
}

\section{«Oberexia»: El deseo de estar (más) gordo en adultos con exceso de peso}

\section{«Oberexia»: O desejo de estar (mais) gordo em adultos com excesso de peso}

\author{
Godoy Izquierdo, D. ${ }^{1,2 *}$, González Hernández, J. ${ }^{1,2}$, Rodríguez Tadeo, A. ${ }^{3}$, Ramírez Molina, M.J. ${ }^{1}$, \\ Navarrón Vallejo, E. ${ }^{1}$, Lara Moreno, R. ${ }^{1}$ y Jiménez Torres, M.G. ${ }^{1,2}$ \\ ${ }^{1}$ Grupo de Investigación CTS-267 Psicología de la Salud y Medicina Conductual. Universidad de \\ Granada. Granada, España; ${ }^{2}$ Departamento de Personalidad, Evaluación y Tratamiento Psicológico. \\ Universidad de Granada. Granada, España; ${ }^{3}$ Departamento Ciencias de la Salud. Universidad \\ Autónoma Ciudad Juárez. Ciudad Juárez, México.
}

\begin{abstract}
Despite of being scarce, evidence is growing on the existence of a group of overweight and obese individuals who do not consider their weight a risk factor for disease and who associate their weight and body with health, vigor, beauty and well-being. Consequently, they manifest a desire to maintain or even increase their weight. We propose an attempt of nomenclature, Oberexia, for this new social reality, and we describe its main characteristics and present empirical observational findings supporting the existence of this condition. The aim of this study was to explore the prevalence and characteristics of Oberexia in a national sample of Spanish 16 to 60-years-old adults. Perceptions of body weight/size/shape and composition, and body satisfaction were assessed in overweight and obese adults through silhouettes, questions and discrepancies. One in ten of the participants self-perceived their body as normal in weight or size. A total of $6.5 \%$ wanted to have overweight or obese bodies. A case-to-case analysis revealed that $4.2 \%$ of the participants wanted to maintain their appearance, and $1.8 \%$ wanted a body with greater weight. All these findings are related to fat mass instead of muscle mass. Our results support the existence of a subgroup of overweight and obese individuals who differ from the traditional subgroup of individuals with excess weight who are dissatisfied with their body. We encourage to explore the outcomes on health and the possible clinical implications of this condition.
\end{abstract}

Key words: Oberexia, weight misperception, body image, body satisfaction, obesity

\section{RESUMEN}

Aunque escasa, existe evidencia creciente sobre la existencia de un grupo de personas con sobrepeso y obesidad que no consideran su exceso de peso un factor de riesgo para la enfermedad y asocian su peso y su cuerpo con salud, vigor, belleza y bienestar. Como consecuencia, manifiestan el deseo mantener o incluso incrementar su peso. Realizamos una propuesta de nomenclatura para esta realidad social, Oberexia, describimos sus principales características y presentamos resultados empíricos observacionales que apoyan la existencia de esta condición. 


\section{Oberexia among adults with excess weight}

Nuestro objetivo fue explorar la prevalencia y características de la Oberexia en una muestra nacional de adultos españoles de 16 a 60 años. Las percepciones de peso/tamaño/forma y composición corporal de personas con sobrepeso y obesidad y su satisfacción corporal fueron evaluadas utilizando siluetas, preguntas y discrepancias. Uno de cada diez participantes percibió su cuerpo como normal en términos de peso y tamaño. Un $6.5 \%$ de los participantes con exceso de peso quería tener cuerpos con sobrepeso u obesidad. Un análisis caso-a-caso reveló que el $4.2 \%$ de los participantes deseaba mantener su apariencia, y el 1.8\% deseaba aumentar de peso. Un 3\% de los participantes podrían ser casos de Oberexia. Estos hallazgos se refieren a masa grasa y no a masa muscular. Nuestros resultados apoyan la existencia de un subgrupo de personas con exceso de peso que difieren del tradicional subgrupo de individuos obesos que se encuentran insatisfechos con su cuerpo. Es momento de explorar las consecuencias para la salud de la Oberexia y las posibles implicaciones clínicas de esta condición.

Palabras clave: Oberexia, distorsión corporal, imagen corporal, satisfacción corporal, obesidad

\section{RESUMO}

Apesar de escassas, crescem as evidências sobre a existência de um grupo de pessoas com sobrepeso e obesidade que não consideram o excesso de peso um fator de risco para a doença e associam seu peso e corpo com saúde, vigor, beleza e bem-estar. Consequentemente, eles manifestam o desejo de manter ou mesmo aumentar seu peso. Fizemos uma proposta de nomenclatura para essa realidade social, Oberexia, descrevemos suas principais características e apresentamos resultados empíricos observacionais que sustentam a existência dessa condição. $\mathrm{O}$ objetivo deste estudo foi explorar a prevalência e as características de Oberexia em uma amostra nacional de adultos espanhóis de 16 a 60 anos. As percepções de peso/tamanho/forma e composição corporal de pessoas com sobrepeso e obesidade e sua satisfação corporal foram avaliadas por meio de silhuetas, perguntas e discrepâncias. Um em cada dez participantes percebeu seu corpo como normal em termos de peso ou tamanho. Um $6.5 \%$ dos participantes com excesso de peso desejava ter corpos com sobrepeso ou obesidade. Uma análise caso-a-caso revelou que $4.2 \%$ dos participantes queriam manter a aparência e $1.8 \%$ desejavam ganhar peso. Un $3 \%$ dos participantes poderia ser casos de Oberexia. Todos esses achados referem-se à massa gorda e não à massa muscular. Nossos resultados confirmam a existência de um subgrupo de indivíduos com sobrepeso e obesidade que diferem do subgrupo tradicional de indivíduos com excesso de peso insatisfeitos com seu corpo. É momento de explorar as consequências para a saúde de a Oberexia e as possíveis implicações clínicas dessa condição.

Palavras-chave: Oberexia, distorção corporal, imagem corporal, satisfação corporal, obesidade

\section{INTRODUCTION}

The World Health Organization (WHO) has affirmed that obesity is the global pandemic of the 21 st century (i.e., globesity) and a first-order health problem because of its high prevalence. According to current figures from the $\mathrm{WHO}$ and the International Association for the Study of Obesity (IASO), one in two adults is overweight (35-40\%) or obese (15-20\%). Alarmingly, obesity prevalence has experienced a growing exponential trend in all world nations in recent decades (International Union of Nutritional Sciences, IUNS, 2015). Achieving a Body Mass Index (BMI) greater than $25 \mathrm{~kg} / \mathrm{m} 2$ is becoming easier and faster given current lifestyles (WHO, 2017). In Spain, $17 \%$ of adults are obese and an additional $36 \%$ are overweight, according to data from the latest editions of the National Health Survey and the European
Health Survey (see also higher prevalence rates in Valdés et al., 2014).

Obesity significantly decreases the health status and quality of life of those who suffer from it and seriously threatens their life expectancy, as it is associated with an increased risk of premature death from any cause, but particularly due to cardiovascular events and cancer (Di Angelantonio et al., 2016). The higher the $\mathrm{BMI}$, the higher is the risk of mortality, up to almost three times higher. Obesity also has important influences on an individual's emotional, cognitive, motivational and behavioral functioning, impairing their well-being, quality of life, interaction with others and personal fulfillment (Scott et al., 2008).

Body image in obesity has been widely researched (e.g., Latner \& Wilson, 2011). In this paper, we draw attention to a subgroup of individuals with excess weight departing from the majority of obese people, 


\section{Godoy Izquierdo, D., González Hernández, J., Rodríguez Tadeo, A., Ramírez Molina, M.J., Navarrón Vallejo, E., Lara Moreno, R. y Jiménez Torres, M.G.}

who tend to have negative body perceptions and low body satisfaction. This is a condition that is hardly reflected in scientific reports and has not being named so far, and its characteristics and manifestations are very little known. We call it «Oberexia» (from $o b$ "over" + orexis - "appetite, desire"). In our proposed conceptualization of Oberexia, this condition is characterized by: 1) a distortion of body perceptions: oberexics have a misperception of their actual weight as normal or even low, i.e., although overweight or obese, they do not perceive themselves as such, but rather as thin, beautiful, strong and healthy. Their body satisfaction is consequently high, and therefore, they would not want to change their body appearance. In fact, in cases of dissatisfaction, the ideal for them would be a body with greater weight and volume, but importantly, only in terms of fat mass, not muscle mass; 2) an alteration in eating behavior: oberexics would engage in eating habits based on hyperphagia and the intake of unhealthy, hypercaloric foods in order to maintain their weight or get the body they want, i.e., one of a greater volume and weight than their current one; and 3) other concomitant weight and body control behaviors, such as a sedentary lifestyle or an almost total inactivity, which contribute to the achievement of the mentioned objective. Figure 1 shows these characteristics graphically. In short, Oberexia is manifested through the ignorance or denial of being overweight and of obesity as a risk factor for disease, distorted positive body perceptions, a desire to have a heavy (heavier) and (more) voluminous body in terms of fat mass, and weightcontrol behaviors aimed at maintaining or increasing weight and improving body satisfaction.

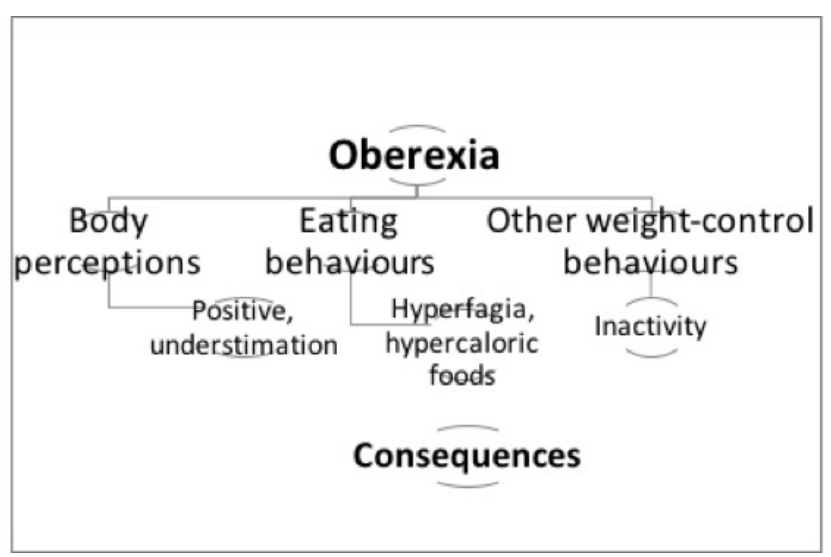

Figure 1. Features of Oberexia.
Our proposal for stating the existence of Oberexia is based on interesting previously published empirical findings about body perceptions and derived behaviors obtained from overweight and obese people. In Oberexia, as stated above, positive body image and high body satisfaction constitute core components. Although most studies exploring body perceptions involving overweight and obese participants do not report subgroups of participants who underestimate their weight, perceive their body as slim or beautiful, are satisfied with their weight and appearance, and consequently admit to engage in behaviors leading to weight maintenance or even increase, some reports do offer findings that point to the existence of this specific profile.

Specifically, regarding perceived and current weight or BMI, misperception of weight status (i.e., discordance between an individual's actual weight status and the perception of their weight status) has repeatedly been documented among overweight and obese adults. It is also known that a high percentage of individuals with excess weight have a distorted view of their body image toward weight or BMI underestimation or toward the consideration of their weight as "normal" or "appropriate" (Atalah, Urteaga \& Rebolledo, 2004; Bhanji et al., 2011; Duncan et al., 2011; Ettarh, van der Vijver, Oti \& Kyobutungi, 2013; Gregory et al., 2008; Mama et al., 2011; Mueller, Hurt, Abu-Lebdeh \& Mueller, 2014; Sámano et al., 2015; Yaemsiri, Slining \& Agarwal, 2011). Controlling for other relevant variables, individuals with excess weight are 5 times more likely to underestimate their weight (Atalah et al., 2004). Moreover, the odds of underassessment are 2 to 3 times higher among overweight and obese individuals who perceive their health as good, and 6 to 12 times higher among those who do not perceive their current weight as a health risk factor, with both phenomena increasing as BMI increases (Gregory et al., 2008).

Some researchers have tried to explore the body satisfaction of people with excessive weight. Findings support that a considerable number of overweight or obese individuals are satisfied with their body, particularly those with a distorted body image (Benkeser, Biritwum \& Hill, 2012; Bhanji et al., 2011; Casillas-Estrella et al., 2006; Ferrari et al., 2012; Millstein et al., 2008; Sámano et al., 2015). In some cases of body dissatisfaction, the desire is for even 


\section{Oberexia among adults with excess weight}

heavier and bulkier bodies (Benkeser et al., 2012; Mama et al., 2011). A high percentage of these individuals take into account not only aesthetic reasons ("looking good", "liking my weight") but also health-related reasons ("it is healthy") for feeling satisfied with their body (Sámano et al., 2015) or for having as an ideal body one corresponding to excess weight BMI categories (Benkeser et al., 2012). Perceptions of positive current health status correlate with body satisfaction among individuals with excessive weight (Millstein et al., 2008). Furthermore, feeling happy with one's own weight and body increases by 6 times the risk of underestimating weight (Bhanji et al., 2011).

Therefore, it is not surprising that many of these individuals consider excessive weight as an ideal, wish to maintain or increase their weight and, consequently, make no attempt to control it, as some research has supported (Benkeser et al., 2012; Duncan et al., 2011; Ettarh et al., 2013; Mama et al., 2011; Mueller et al., 2014; Yaemsiri et al., 2011). Weight underestimation decreases by 50 to $70 \%$ the probability of wanting or trying to lose weight (Duncan et al., 2011).

These findings could indicate a social reality largely ignored to date that would have important health implications, a condition in which overweight and obese individuals perceive themselves as having healthy, beautiful and functional bodies and wish to maintain their weight or even increase it. However, none of the above-mentioned studies aimed at identifying specifically this group of obese individuals; instead, the findings for these figures are mixed with the general results obtained with the whole samples studied.

Based on such findings, which indicate that, among overweight and obese people, there may be individuals who are satisfied with their body and even willing to have heavier or larger bodies (but not athletic ones, with greater weight or size linked to greater muscularity), the present study was specifically designed to estimate the prevalence of Oberexia. With this aim in mind and covering the whole national territory, we explored body perceptions of Spanish individuals in their early and middle adulthood and with excess weight. Specifically, we explored their body perceptions, their body ideals and their body satisfaction, differentiating between two components of body composition, weight and muscularity, in order to rule out the desire to have a (more) heavy and voluminous body due, actually, to the valuation of an athletic body as the ideal appearance. One important characteristic of the above-mentioned studies is that none of them considered the dimension of muscularity (vs. weight) in their evaluation of body perceptions (Thompson \& Cafri, 2007), nor the possible differences by gender in relation to this issue. It is noteworthy that none of the reviewed studies explored the possible prevalence of Oberexia neither in the general population nor in specific clinical populations (i.e., individuals with obesity), and thus, this study can make an important contribution to this area of research.

\section{MATERIALS AND METHODS}

\section{Participants}

A total of 1022 Spanish men $(22.4 \%)$ and women $(77.6 \%)$ aged 16 to 60 years old $(\mathrm{M}=25.22, \mathrm{SD}=$ 6.39) voluntarily participated in a parent study on body perceptions and health-related issues (Ramírez et al., 2018). They were recruited from the general population through an online survey, thus forming a non-random sample of convenience throughout the national territory. According to BMI categories (WHO, 2000), 5.1\% were underweight $(<18.5$ $\mathrm{kg} / \mathrm{m} 2), \quad 59.8 \%$ were normal weight (18.6-24.9 $\mathrm{kg} / \mathrm{m} 2), 12.2 \%$ were overweight $(25-29.9 \mathrm{~kg} / \mathrm{m} 2)$ and $4.2 \%$ were obese $(\geq 30 \mathrm{~kg} / \mathrm{m} 2)$ (data unknown for $18.7 \%$ of participants). In the present study, only data corresponding to the 168 participants in the categories of overweight and obesity were considered. Their average age was $26.76 \pm 7.38$ years old, and $64.9 \%$ of them were women. Other sociodemographic data are shown in Table 1. Importantly, $8.3 \%$ had suffered or suffered at the time of the study from some type of eating disorder (ED). Only 3 participants indicated that they were obese when asked about current illnesses.

\section{Measures}

Information was collected regarding age, sex, nationality, educational level, employment status, marital status, children (yes/no, if woman: number of pregnancies and age at which the first and last children were born; current pregnancy), whether suffering from any illness and taking any medication or following any treatment or therapy at the time of the study, and, 


\section{Godoy Izquierdo, D., González Hernández, J., Rodríguez Tadeo, A., Ramírez Molina, M.J., Navarrón Vallejo, E., Lara Moreno, R. y Jiménez Torres, M.G.}

further, whether suffering at the time of the study or had ever had an ED, with indication of the diagnosis, type or main clinical manifestations.

\section{Table 1}

Sociodemografic characteristics $N=168$

\begin{tabular}{|c|c|c|}
\hline Variable & Level & $\%$ \\
\hline EDUCATIONAL & No studies, Primary school & 3 \\
\hline \multirow[t]{5}{*}{ LEVEL } & Secondary school & 5.4 \\
\hline & Vocational training & 8.9 \\
\hline & University & 71.4 \\
\hline & Postgrade (Master, Doctorate) & 10.1 \\
\hline & Unknown & 1.2 \\
\hline \multirow[t]{4}{*}{ WORK STATUS } & Studying & 61.3 \\
\hline & Active & 26.2 \\
\hline & Unemployed & 12.5 \\
\hline & Retired & 0 \\
\hline FAMILY & $<1000 €$ & 29.8 \\
\hline \multirow[t]{3}{*}{ INCOME } & $1000-2000 €$ & 42.3 \\
\hline & $2000-3000 €$ & 19 \\
\hline & $>3000 €$ & 8.9 \\
\hline MARITAL & Single & 38.7 \\
\hline \multirow[t]{3}{*}{ STATUS } & No stable relationship $(<1 \mathrm{yr})$ & 8.9 \\
\hline & Stable relationship ( $>1 \mathrm{yr})$ & 50.6 \\
\hline & Separated, divorced, widow(er) & 1.8 \\
\hline PREGNANCY & Yes & 6.6 \\
\hline (women) & Unknown & 20.8 \\
\hline \multirow[t]{8}{*}{ ILLNESS } & Yes, of which & 24.4 \\
\hline & $\begin{array}{l}\text { Metabolic (hypothyroidism, } \\
\text { diabetes, hypercholesterolemia, } \\
\text { hypertriglyceridemia...) }\end{array}$ & 7.2 \\
\hline & $\begin{array}{l}\text { Cardiovascular (hypertension, heart } \\
\text { failure, vascular diseases, } \\
\text { migraines...) }\end{array}$ & 3.6 \\
\hline & $\begin{array}{l}\text { Musculoskeletal } \quad \text { (rheumatoid } \\
\text { arthritis, arthrosis, scoliosis, } \\
\text { lumbalgia, luxation, paraparesis...) }\end{array}$ & 3.6 \\
\hline & Asthma and/or allergy & 3.6 \\
\hline & Digestive (irritable bowel, colitis...) & 1.8 \\
\hline & Polycystic Ovary Syndrome & 1.2 \\
\hline & Anxiety, depression & 1.2 \\
\hline THERAPY & Yes & 21.4 \\
\hline EATING & Yes, of which & 8.4 \\
\hline \multirow[t]{9}{*}{ DISORDER } & Bulimia & 1.8 \\
\hline & Bulimia and anorexia & 1.8 \\
\hline & Binge eating & 0.6 \\
\hline & Bulimia and binge eating & 0.6 \\
\hline & Anorexia & 0.6 \\
\hline & Orthorexia & 0.6 \\
\hline & Food anxiety & 0.6 \\
\hline & $\begin{array}{l}\text { Intense distress (dysfunctional and } \\
\text { incapacitating) regarding food and } \\
\text { weight, with no specific diagnosis }\end{array}$ & 0.6 \\
\hline & Unknown & 1.2 \\
\hline
\end{tabular}

Body perceptions were assessed using anatomical models or silhouettes corresponding to progressive values of BMI and muscularity (adapted from Oliveira et al., 2011). Two blocks of 15 anatomical models were presented, and the participant had to indicate which one they considered to be the figure that best suited their current body (perceived body, PBI) and which one they would like to have (ideal body, IBI). In both cases, a double assessment was included, referring both to the body size (from $1=$ Very obese to $8=$ Very thin) as well as to the corporal constitution (from $8=$ Very flaccid to $15=$ Very muscular) in order to simultaneously evaluate body shape, weight or size, and body composition or muscularity. The central image corresponds to the silhouette that is the fusion between weight and muscular tone. Male silhouettes were used for men, and female silhouettes for women (Thompson, 2004). Silhouettes have been widely used to evaluate the perceptual representations of the body, usually with different figures in terms of body size or weight (Ettarh et al., 2013; Mama et al., 2011; Sámano et al., 2015) and more rarely of structure or body composition, and have good psychometric properties as well as cross-cultural validity (Gardner \& Brown, 2010).

Complementarily, participants' perceptions of weight and muscularity were also assessed using two facevalid questions ("I perceive myself as...", from $0=$ Very thin to $7=$ Very obese; "I think my body composition is...", from $0=$ Very flimsy/flabby to $7=$ Very strong/muscular). These types of questions have been previously used (e.g., Benton \& Karazsia, 2015).

Body satisfaction was assessed using two indicators: A face-valid item ("How satisfied are you with your current body weight, size and appearance?", $0=$ Not satisfied at all to $7=$ Highly satisfied) (Ramírez et al., 2018), as well as the discrepancy between the PBI and IBI (Casillas-Estrella et al., 2006; Oliveira et al., 2011; Ramírez et al., 2018). Both strategies have shown appropriate psychometric properties.

\section{Procedure}

The online survey was made available to the community via the LimeSurvey ${ }^{\circledR}$ tool, and the public was informed using various means (e.g., university campuses, e-mail distribution lists, social forums on the internet). On the first page, detailed information was offered about the study and its main objectives, its voluntary, anonymous and confidential nature, as well as participants' tasks and rights. Next, the procedure to answer the questionnaires was explained. Having read 


\section{Oberexia among adults with excess weight}

this information, all the participants provided online informed consent to participate and then entered the survey.

No a priori limits were established for participation (except age $\geq 16$ years old), allowing anyone interested in collaborating to participate. It was possible to temporarily store incomplete data and retrieve them later using a password. Once the survey was answered and closed, the data were automatically stored in a database, which was downloaded and reviewed with extreme care in order to decide the final participants based on technical aspects (i.e., duplicate data, incomplete surveys) and inclusion criteria (i.e., age between 16 and 60 years old, Spanish nationality, no current pregnancy, no severe mental problems or disability, not being a federated athlete).

This study meets the ethical requirements of the Declaration of Helsinki and was approved by the Ethics Committee for Human Research of the authors' institution.

\section{Study design and statistical analyses}

This is a descriptive, correlational study with a crosssectional design. Exploratory data analyses were carried out in order to detect and correct errors in the database, lost or absent data and outliers. Descriptive analyses were performed, concretely the calculation of the mean and standard deviation for continuous variables and $\mathrm{n}$ and the percentage for categorical variables.

\section{RESULTS}

In terms of the whole sample, the participants perceived their bodies as overweight and not athletic (see Table 2). The participants' ideal body indicates that they would like to have thinner and more toned bodies. The discrepancy between their selfperceptions and their ideal body image is noticeable. Consequently, the participants showed moderate body satisfaction.
Table 2

Descriptive findings $N=168$

\begin{tabular}{lcccc}
\hline $\begin{array}{l}\text { Variables (Range of possible } \\
\text { scores) }\end{array}$ & M & SD & Min & Max \\
\hline PBI-Sillouethes (1 - 15) & 5.07 & 2.54 & 1 & 13 \\
Weight self-perceptions (0 - 7) & 4.43 & 0.89 & 2 & 7 \\
$\begin{array}{l}\text { Muscularity self-perceptions } \\
(0-7)\end{array}$ & 3.81 & 1.52 & 0 & 7 \\
IBI-Sillouethes (1 - 15) & 9.12 & 2.59 & 3 & 15 \\
$\begin{array}{l}\text { Discrepancy PBI-IBI (-14 - } \\
\text { 14) }\end{array}$ & -4.05 & 2.58 & -11 & 4 \\
BS $(0-7)$ & 3.15 & 1.56 & 0 & 7 \\
\hline
\end{tabular}

PBI: perceived body image; IBI: ideal body image; PBI-IBI: Discrepancy between perceived and desired bodies; BS: body satisfaction.

Nevertheless, a deeper analysis of the data revealed different realities within the sample (see Table 3). Among the participants, $10.7 \%$ perceived their body as being normal in weight or size. The specific questions about weight and body composition make it possible to better understand the participants' body perceptions, confirming different profiles of body image. In addition, a significant number wished to have overweight or obese bodies, specifically $6.5 \%$. Furthermore, considering the PBI-IBI discrepancy, $4.2 \%$ of participants said they wanted to maintain their appearance and figure, and $1.8 \%$ indicated that they wanted a body with greater weight and size in terms of fat mass (indicating a desire for a body with a size 1 to 4 levels higher on the scale of silhouettes). In terms of body satisfaction, approximately two in three participants indicated being moderately to highly satisfied with their body.

We conducted a case-to-case analysis of all the combinations of the study variables (data not shown, available upon request), which, along with the previous findings, helped us for the following final analysis. In total, ten participants wanted to maintain or increase their weight (PBI-IBI discrepancy null or positive). A more exhaustive analysis of these cases (see Table 4), considering both the perceptions of weight and muscularity as well as the desired bodies and body satisfaction, leads us to conclude that of all cases, five (3\% of the sample) could be cases of Oberexia. 


\section{Godoy Izquierdo, D., González Hernández, J., Rodríguez Tadeo, A., Ramírez Molina, M.J., Navarrón Vallejo, E., Lara Moreno, R. y Jiménez Torres, M.G.}

Table 3

Percentage of participants indicating each level of body perceptions $N=168$

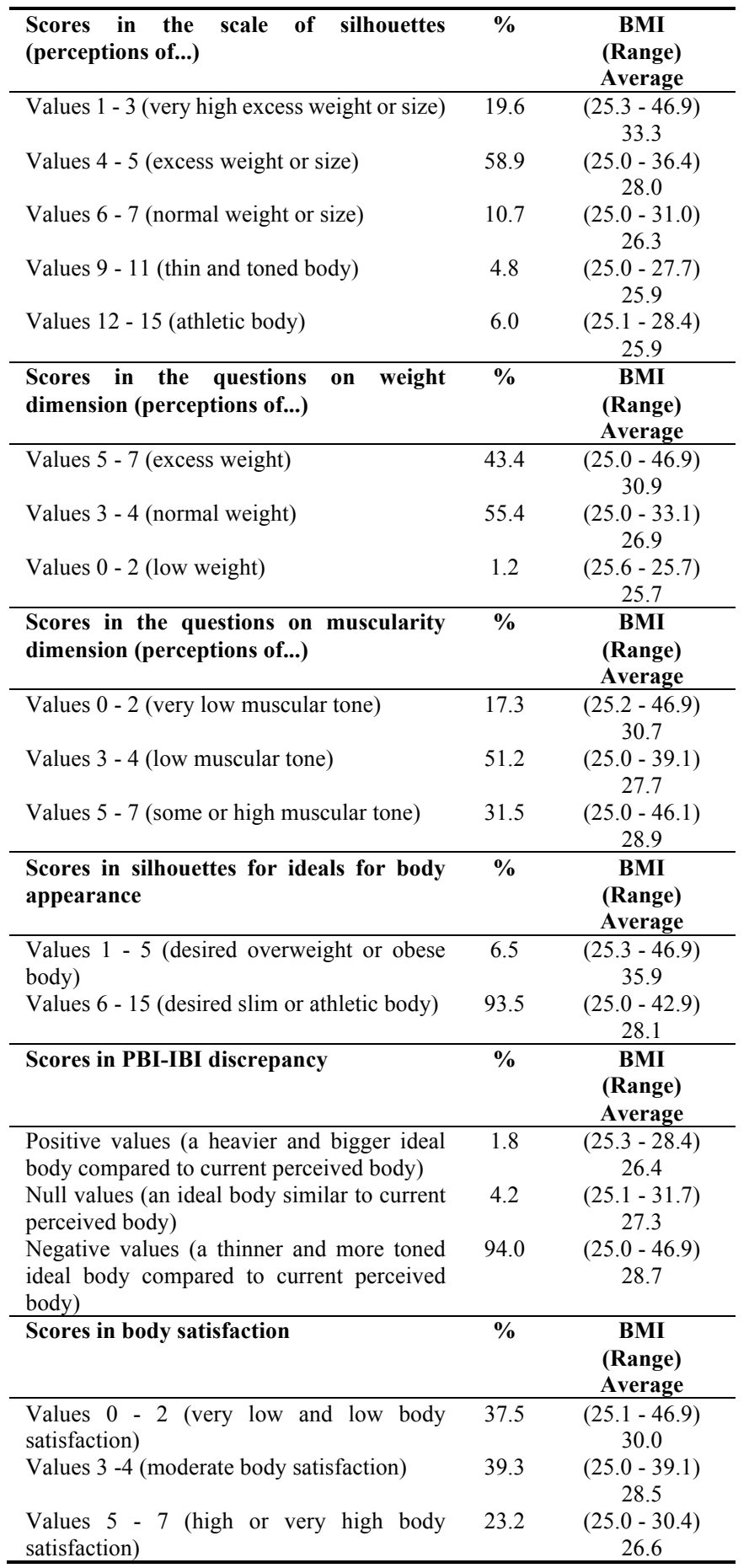

Among them, case number 4 (Table 4) stands out as a good indicator of Oberexia: body perceptions of obesity, excess weight and low muscularity, body ideals with excess weight and a low body satisfaction along with a desire to gain weight (and not muscularity). The remaining five cases seem to be participants with athletic bodies wishing to maintain or increase their weight and muscularity level, although there were two cases in which the desired body was less muscular. Figure 2 displays these findings along with those obtained for the whole sample.

\section{Table 4}

Combinations of scoring levels on the main variables in cases of null or positive PBI-IBI discrepancy $n=10$

\begin{tabular}{lccccccc}
\hline & BMI & PBI & Wei & Mus & IBI & $\begin{array}{c}\text { PBI- } \\
\text { IBI }\end{array}$ & BS \\
\hline Possible & 31.7 & 4 & 4 & 5 & 4 & 0 & 4 \\
Oberexia & 28.4 & 5 & 4 & 4 & 5 & 0 & 4 \\
case & 29.4 & 5 & 5 & 4 & 5 & 0 & 5 \\
& 25.3 & 5 & 5 & 3 & 3 & 2 & 2 \\
& 25.6 & 6 & 4 & 4 & 6 & 0 & 5 \\
Possible & 25.5 & 11 & 3 & 5 & 11 & 0 & 6 \\
athletic & 25.1 & 12 & 4 & 7 & 12 & 0 & 5 \\
profile & 25.6 & 13 & 3 & 5 & 13 & 0 & 7 \\
& 25.5 & 13 & 4 & 4 & 9 & 4 & 3 \\
& 28.4 & 13 & 5 & 5 & 12 & 1 & 5 \\
\hline
\end{tabular}

PBI: perceived body image; Wei: Weight; Mus: Muscularity; IBI: ideal body image; PBI-IBI: Discrepancy between perceived and desired bodies; BS: body satisfaction.

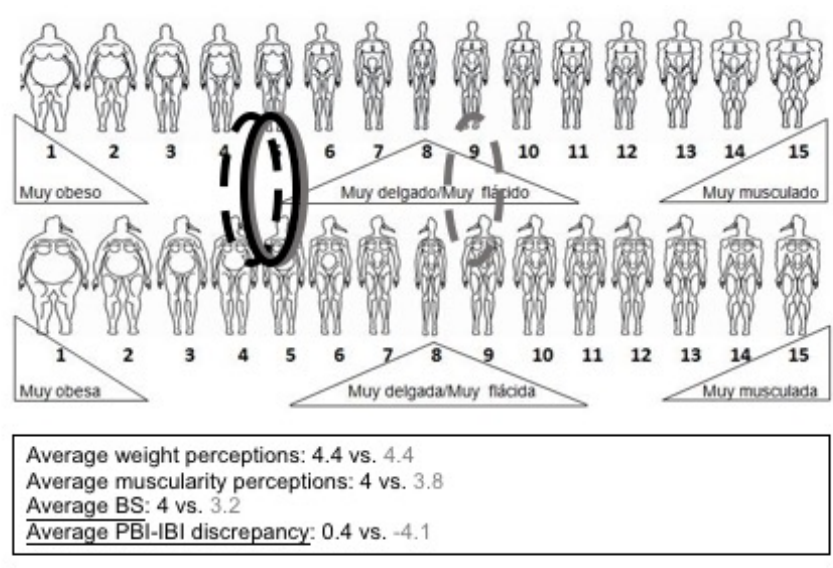

Figure 2. Participants' current body self-perceptions (complete line) and desired body self-perceptions (dotted 


\section{Oberexia among adults with excess weight}

line). Grey: Whole sample $\mathrm{N}=168$. Black: Possible cases of Oberexia $n=5$.

\section{DISCUSSION}

In the present study, we aimed to estimate the prevalence of Oberexia, identifying possible cases in a Spanish sample of 16 to 60 -years-old individuals who were overweight or obese. According to the multidimensional theory of body perceptions of Thompson, Heinberg, Altabe and Tantleff-Dunn (1999), body image is a multifaceted construct that encompasses self-perceptions of the body and appearance, including thoughts, beliefs, values, attitudes, emotions and behaviors grouped in a perceptual dimension (i.e., accuracy in the estimation of the body or its parts in terms of size, shape or weight), a cognitive-affective dimension (i.e., subjective experiences related to the body or any of its parts, including (dis)satisfaction) and a behavioral dimension (i.e., behaviors derived from body perceptions or to manage body appearance). Therefore, body image incorporates the estimation of body size and shape, the evaluation of its attractiveness, the subjective satisfaction with these perceptions and the emotions and actions associated with them (Cash \& Smolak, 2011; Grogan, 2017). In this study, we have explored two of these dimensions to identify possible cases of Oberexia: the perceptual component, measured through silhouettes considering weight and body composition as well as specific questions for size and muscularity, thus establishing a differentiation between both components of body composition in order to rule out that the desire to have a more voluminous body could in fact be due to the valuation of an athletic body as the ideal body; and the subjective component, evaluated through satisfaction with body perceptions.

The findings of the studies reviewed, as well as those from the present study when the complete sample was considered, indicated that most people with excess weight perceive themselves as overweight and obese (even when they have no accurate perceptions of weight), have reduced body satisfaction and would like to have thinner bodies, in a linear relation to BMI. This may reflect the currently accepted socio-cultural beauty stereotypes, according to which men believe that the masculine ideal body is slim and muscled, athletic-type, and they evaluate their appearance according to it (Thompson \& Cafri, 2007), and women believe that the current feminine ideal emphasizes being thin, but also having a toned and muscle-defined body (Benton \& Karazsia, 2015; Cash \& Smolak, 2011).

Simultaneously, however, findings lead us to conclude that there is a subgroup of overweight and obese individuals whose body perceptions do not match the reality of their body, who perceive themselves as thinner than they are, who take great satisfaction in having such a kind of body and who would like to be even heavier or larger. In addition, there are obese individuals who perceive themselves as such but are also satisfied with their appearance and have a positive judgment of obesity and being overweight (Sámano et al., 2015). The most important contribution of this study is to have confirmed, for the first time in a study specifically focused on this purpose, the existence of a small but interesting subgroup of people with excess weight whose body perceptions are distorted in a positive fashion, who experience a high degree of satisfaction with their body and who wish to maintain this condition. Approximately one in 10 participants perceived themselves as being normal in weight or size and one in 20 as being thin and having somewhat muscular bodies. Moreover, one in 15 wanted to have an overweight or obese body, and one in 55 wanted a heavier/bigger body. The use of silhouettes corresponding to different degrees of BMI and muscularity, as well as specific questions related to weight and body composition, allowed us to distinguish between those who have an assessment of their current and ideal body in terms of athletic vs. obese bodies.

According to our findings, among individuals with excess weight, up to $3 \%$ may be at risk of suffering or already suffer from Oberexia. Therefore, and particularly due to its possible consequences for health (e.g., high risk of morbidity and mortality associated with obesity and severe obesity), Oberexia should be more thoroughly investigated as a condition with a high relevance for public health. Our results should be taken with caution because they are only preliminary, but they may attract the attention of researchers and health officials in order to continue research in this field.

Furthermore, EDs are common among overweight and obese individuals. Obesity is a risk factor for EDs, and in a very high percentage of cases both conditions 


\section{Godoy Izquierdo, D., González Hernández, J., Rodríguez Tadeo, A., Ramírez Molina, M.J., Navarrón Vallejo, E., Lara Moreno, R. y Jiménez Torres, M.G.}

coexist. Several reviews and meta-analyses as well as clinical and epidemiological studies link obesity with anorexia and, more frequently, with disorders with a bulimic/binge-eating component (Hill, 2007). In addition, obesity and EDs share similar risk factors, particularly those related to socio-cultural pressures regarding the body and the prevailing beauty canons, dissatisfaction with body perceptions and risk behaviors for weight and appearance control (Haines \& Neumark-Sztainer, 2006). This has led to the proposal of including obesity along with EDs within a broad spectrum of weight-related disorders (SánchezCarracedo, Neumark-Sztainer \& López-Guimera, 2012). Moreover, although each ED is characterized by a specific conglomerate of clinical manifestations, it has been proposed that the main cause of all EDs and their fundamental psychopathological nucleus is a distortion of body perceptions (Fairburn, Cooper \& Shafran, 2003; Fairburn \& Cooper, 2011). Noteworthy, the prevalence of Oberexia found in the present study is similar or significantly higher than that of EDs (e.g., Smink, van Hoeken \& Hoek, 2012). Consequently, we encourage the exploration of Oberexia in relation to EDs, considering their main clinical characteristics.

This study suffers from some limitations that should be conveniently addressed in the future. First of all, although the initial sample was of a considerable size and nation-wide, the subsample of overweight and obese individuals was reduced and does not parallel national data on obesity prevalence (Valdés et al., 2014). Furthermore, we were not able to disaggregate by sex because of the small number of participants. However, excess female body weight is valued in many places due to racial/ethnic and socio-cultural influences (Benkeser et al., 2012; Duncan et al., 2011; Yaemsiri et al., 2011). Moreover, excess body weight has generally been associated with wealth and health and considered a desirable attribute in many nations, particularly in economically deprived ones (Benkeser et al., 2012; Ettarh et al., 2013). Thus, in future studies, larger samples should be used ensuring the heterogeneity and representativeness of the participants in order to replicate our findings in people of both sexes with different educational and socioeconomical levels and ethnic-cultural backgrounds.

Secondly, a major limitation is not having considered the behavioral practices used by the participants for weight, body and appearance management, which constitute the third dimension of body perceptions according to the model of Thompson et al. (1999) (i.e., the behavioral dimension, referring to the use of healthy or risky strategies for self-regulating the body). When researching on Oberexia, it is very important to explore the consequences at a behavioral level derived from positive body perceptions as well as high satisfaction with them in obesity. In our proposal of Oberexia, these behavioral strategies are risky practices because they would allow one to maintain a high weight or even increase it in an already morbid condition, obesity, thus seriously compromising health status and quality of life. Future research should explore these weight-regulating behaviors as well as their role in Oberexia. This is an extremely relevant issue given that interventions promoting lifestyle modifications for weight control face a difficult task in encouraging behavioral changes and are likely to have little impact on an individual who does not believe that she/he is overweight or that being overweight puts one at risk for increased morbidity (Gregory et al., 2008).

Thirdly, we based our data on self-reports. Self-reports are appropriate for the assessment of body perceptions and body satisfaction but should be complemented with objective data (e.g., structural parameters for BMI calculation). There is a debate on BMI for the detection of excess weight (Ramos-Silva, SavegnagoMialich, Hoffman \& Jordao, 2017), but findings supports its utility (Doménech-Asensi et al., 2018). In addition, no differences have been found between selfreported and measured weight, height and BMI (Bibiloni et al., 2016). Moreover, like in other studies (Benton \& Karazsia, 2015), an online survey was used to collect the data, so it is possible that only those individuals with economic or educational resources allowing access to it or those highly motivated to collaborate in this type of studies might have participated. Although some criticisms have been applied to online assessments (e.g., sample biases, withdrawal, lack of control), we followed published recommendations in order to potentiate its multiple advantages and to enhance quality (e.g., International Test Commission, 2006).

Finally, this is a descriptive study whose aim was the identification and exploration of a subgroup of individuals with excessive weight who have body 


\section{Oberexia among adults with excess weight}

distortions towards low weight and who consider fatness to be "healthy" and "beautiful". Future research should use other methodological resources (e.g., qualitative and mixed quantitative-qualitative methodologies), research designs and analytical procedures to deepen the description, identification and differentiation of Oberexia.

\section{CONCLUSIONS}

In conclusion, this study has attempted to present clues leading to the existence of Oberexia, which should deserve greater research and clinical efforts because of its potential importance at the social, sanitary and personal levels. It is very likely that this condition is already affecting an important part (3\% based on our findings, in line with the prevalence of EDs) of the population with excess weight, and it is extremely dangerous due to its potentially associated morbidity and mortality risks. Oberexic individuals not only do not perceive excess weight as a threat to their health but also value overweight and obesity in a positive way, so that their behavioral efforts will be aimed at maintaining or even increasing the weight and volume of their body, with the high risks that this would entail. At the applied level, it is important to make advances in the detection and preventive and therapeutic approach of this condition in line with EDs therapies (APA, 2013). Individuals suffering from Oberexia might thus benefit from interventions aimed not only at weight control (obesity) but also at ED management (body image).

Acknowledgements. This research was partially supported with the financial aid conceded to the Research Project "Calidad de vida y percepción de la imagen corporal en adultos con obesidad" (Ref. ICB2) by the Universidad Autónoma Ciudad Juárez, México (Proyectos Programa Institucional de Investigación Aplicada para la Vinculación del Entorno y la Atención de Problemas Específicos-PIVA), and to the "Psicología de la Salud/Medicina Conductual" Research Group (CTS-0267) by the Junta de Andalucía (Spain). We are grateful to all the participants and assistants who made this study possible.

\section{REFERENCES}

American Psychiatric Association (2013). Diagnostic and statistical manual of mental disorders (DSM-5®). Arlington, VA: American Psychiatric Association.

Atalah, E.S., Urteaga, C.R., \& Rebolledo, A.A. (2004). Autopercepción del estado nutricional en adultos de Santiago. Revista Médica de Chile, 132, 1383-8.

Benkeser, R.M., Biritwum, R., \& Hill, A.G. (2012). Prevalence of overweight and obesity and perception of healthy and desirable body size in urban, Ghanaian women. Ghana Medical Journal, 46(2), 66-75.

Benton, C., \& Karazsia, B.T. (2015). The effect of thin and muscular images on women's body satisfaction. Body Image, 13, 22-7.

Bhanji, S., Khuwaja, A.K., Siddiqui, F., Azam, I., \& Kazmi, K. (2011). Underestimation of weight and its associated factors among overweight and obese adults in Pakistan: A cross sectional study. BMC Public Health, 11(1), 363-70.

Bibiloni, M.M., Coll, J.L., Salas, R., Pich, J., Pons, A., \& Tur, J.A. (2016). Ten-year trends (2000-2010) in bias of self-reported weight, height and body mass index in a Mediterranean adult population. Nutrición Hospitalaria, 33(6), 1367-71.

Cash, T.F., \& Smolak, L. (2011). Body image: A handbook of science, practice, and prevention (2 ed.). New York, NY: Guilford Press.

Casillas-Estrella, M., Montaño-Castrejón, N., ReyesVelázquez, V., Bacardí-Gascón, M., \& Jiménez-Cruz, A. (2006). A mayor IMC mayor grado de insatisfacción de la imagen corporal. Revista Biomédica, 17(4), 243-9.

Di Angelantonio, E., Bhupathiraju, S.N., Wormser, D., Gao, P., Kaptoge, S., de Gonzalez, A.B., et al. (2016). Body-mass index and all-cause mortality: Individualparticipant-data meta-analysis of 239 prospective studies in four continents. The Lancet, 388, 776-86.

Doménech-Asensi, G., Gómez-Gallego, C., RosBerruezo, G., García-Alonso, F.J., \& CanterasJordana, M. (2018). Visión crítica de los métodos antropométricos actuales en comparación con un nuevo índice para la detección precoz de sobrepeso en estudiantes universitarios españoles: El Índice 


\section{Godoy Izquierdo, D., González Hernández, J., Rodríguez Tadeo, A., Ramírez Molina, M.J., Navarrón Vallejo, E., Lara Moreno, R. y Jiménez Torres, M.G.}

Normalizado Ajustado al Peso. Nutrición Hospitalaria, 35(2), 359-67.

Duncan, D.T., Wolin, K.Y., Scharoun-Lee, M., Ding, E.L., Warner, E.T., \& Bennett, G.G. (2011). Does perception equal reality? Weight misperception in relation to weight-related attitudes and behaviors among overweight and obese US adults. International Journal of Behavioral Nutrition and Physical Activity, 8(1), 20.

Ettarh, R., van der Vijver, S., Oti, S., \& Kyobutungi, C. (2013). Overweight, obesity, and perception of body image among slum residents in Nairobi, Kenya, 20082009. Preventing Chronic Disease, 10, 130198.

Fairburn, C.G., Cooper, Z., \& Shafran, R. (2003). Cognitive behaviour therapy for eating disorders: A "transdiagnostic" theory and treatment. Behaviour Research and Therapy, 41, 509-28.

Fairburn, C.G., \& Cooper, Z. (2011). Eating disorders, DMS-5, and clinical reality. British Journal of Psychiatry, 198, 8-10.

Ferrari, E.P., Gordia, A.P., Martins, C.R., Silva, D.A., Quadros, T.M., \& Petroski, E.L. (2012). Insatisfação com a imagem corporal e relação com o nível de atividade física e estado nutricional em universitários. Motricidade, 8(3), 52-8.

Gardner, R.M., \& Brown, D.L. (2010). Body image assessment: A review of figural drawing scales. Personality and Individual Differences, 48(2), 107-11.

Gregory, C.O., Blanck, H.M., Gillespie, C., Maynard, L.M., \& Serdula, M.K. (2008). Health perceptions and demographic characteristics associated with underassessment of body weight. Obesity, 16(5), 97986.

Grogan, S. (2017). Body image: Understanding body dissatisfaction in men, women, and children (3 ed.). New York, NY: Routledge.

Haines, J., \& Neumark-Sztainer, D. (2006). Prevention of obesity and eating disorders: A consideration of shared risk factors. Health Education \& Research, 21(6), 770-82.
Hill, A.J. (2007). Obesity and eating disorders. Obesity Reviews, 8(s1), 151-5.

International Test Commission (2006). International guidelines on computer-based and internet-delivered testing. International Journal of Testing, 6(2), 143-71.

International Union of Nutritional Sciences (2015). The global challenge of obesity and the International Obesity Task Force [Online]. Retrieved from http://www.inus.org/.

Latner, J.D., \& Wilson, R.E. (2011). Obesity and body image in adulthood. In T.F. Cash, \& L. Smolak (eds.), Body image: A handbook of science, practice, and prevention (pp. 189-97). New York, NY: Guilford Press.

Mama, S.K., Quill, B.E., Fernandez-Esquer, M.E., Reese-Smith, J.Y., Banda, J.A., \& Lee, R.E. (2011). Body image and physical activity among Latina and African American women. Ethnicity \& Disease, 21(3), 281-7.

Millstein, R.A., Carlson, S.A., Fulton, J.E.G., Galuska, D.A., Zhang, J., Blanck, H.M., \& Ainsworth, B.E. (2008). Relationships between body size satisfaction and weight control practices among US adults. Medscape Journal of Medicine, 10(5), 119.

Mueller, K.G., Hurt, R.T., Abu-Lebdeh, H.S., \& Mueller, P.S. (2014). Self-perceived vs actual and desired weight and body mass index in adult ambulatory general internal medicine patients: A cross sectional study. BMC Obesity, 1(26), 1-9.

Oliveira, V., Macedo, J., Silva, J., Perrout de Lima, J., Fernandes, H.M., \& Machado, V. (2011). Relationship between anthropometric variables and body image dissatisfaction among fitness center users. Revista de Psicología del Deporte, 20(2), 367-82.

Ramírez, M.J., Godoy-Izquierdo, D., Navarrón, E., Jiménez-Torres, M.G., \& Godoy, J.F. (2018). Estrategias para el manejo del cuerpo en adultos jóvenes: Interacción entre las percepciones corporales, la edad y el sexo. Behavioral Psychology, 26(2), 33757.

Ramos-Silva, B., Savegnago-Mialich, M., Hoffman, D., \& Jordao, A.A. (2017). BMI, BMIfat, BAI or 


\section{Oberexia among adults with excess weight}

BAIFels-Which is the best adiposity index for the detection of excess weight? Nutrición Hospitalaria, 34(2), 389-95.

Sámano, R., Rodríguez-Ventura, A.L., SánchezJiménez, B., Godínez, E.Y., Noriega, A., Zelonka, R., et al. (2015). Satisfacción de la imagen corporal en adolescentes y adultos mexicanos y su relación con la autopercepción corporal y el índice de masa corporal real. Nutrición Hospitalaria, 31(3), 1082-8.

Sánchez-Carracedo, D., Neumark-Sztainer, D., \& López-Guimera, G. (2012). Integrated prevention of obesity and eating disorders: Barriers, developments and opportunities. Public Health Nutrition, 15(12), 2295-309.

Scott, K.M., Bruffaerts, R., Simon, G.E., Alonso, J., Angermeyer, M., de Girolamo, G., et al. (2008). Obesity and mental disorders in the general population: Results from the World Mental Health Surveys. International Journal of Obesity, 32(1), 192200.

Smink, F.R., van Hoeken, D., \& Hoek, H.W. (2012). Epidemiology of eating disorders: Incidence, prevalence and mortality rates. Current Psychiatry Reports, 14(4), 406-14.

Thompson, J.K. (2004). The (mis)measurement of body image: Ten strategies to improve assessment for applied and research purposes. Body Image, 1(1), 7 14.

Thompson, J.K., \& Cafri, G. (2007). The muscular ideal: Psychological, social and medical perspectives. Washington, DC: APA.

Thompson, J.K., Heinberg, L.J., Altabe, M., \& TantleffDunn, S. (1999). Exacting beauty: Theory, assessment, and treatment of body image disturbance. Washington, DC: APA.

Valdés, S., García-Torres, F., Maldonado-Araque, C., Goday, A., Calle-Pascual, A., Soriguer, F., et al. (2014). Prevalence of obesity, diabetes and other cardiovascular risk factors in Andalusia (southern Spain). Comparison with national prevalence data. The Di@bet.es study. Revista Española de Cardiología, 67(6), 442-8.
WHO (2000). Obesity: Preventing and managing the global epidemic. Geneve: World Health Organization.

WHO (2017). Obesidad y sobrepeso. [Online]. Retrieved from http://www.who.int/es/news-room/factsheets/detail/obesity-and-overweight.

Yaemsiri, S., Slining, M.M., \& Agarwal, S.K. (2011). Perceived weight status, overweight diagnosis, and weight control among US adults: The NHANES 2003-2008 Study. International Journal of Obesity, $35,1063-70$. 